total), and the solution was stirred for $12 \mathrm{~h}$ at $25^{\circ} \mathrm{C}$. The reaction mixture was applied to a small column of Dowex $50 \times 8\left(\mathrm{H}^{+}\right)$, and it was eluted with distilled water $(2.5 \mathrm{~mL})$. The eluent was neutralized with $10 \% \mathrm{NaOH}(67 \mu \mathrm{L})$, a solution of phenacyl bromide $(43.4 \mathrm{mg})$ in acetone $(2.5 \mathrm{~mL})$ was added, and the reaction mixture was refluxed for $2 \mathrm{~h}$. The acetone was removed by rotary evaporation, and the remaining aqueous phase was extracted with ether. The ether extract was dried and concentrated, and the residue was purified by preparative thin-layer chromatography (silica gel GF, Analtech Uniplate Taper Plates, chloroform solvent). A band with $R_{f} 4.5-5.5$ was scraped off the plate and eluted with chloroform to yield a mixture of the phenacyl esters of 3-hydroxy-3-methylpentanoic acid and maleic acid. The former compound proved to be exclusively the $R$ isomer as judged by ${ }^{1} \mathrm{H}$ NMR in the presence of the chiral shift reagent $(-)-\mathrm{Eu}(\mathrm{hfc})_{3}$ (see Figure 1).

Acknowledgment. This work was supported by $\mathrm{Na}$ tional Institutes of Health Grants GM31801 and AI24146 and by an Alfred P. Sloan Research Fellowship (to R.A.P.).

Supplementary Material Available: NMR spectra of compounds $3,5,6$, and 8 (5 pages). Ordering information is given on any current masthead page.

\section{Calix[4]arenes Bridged at the Lower Rim}

Jan-Dirk van Loon, ${ }^{\dagger}$ Dagmar Kraft, ${ }^{\ddagger}$ Marc J. K. Ankonê, ${ }^{\dagger}$ Willem Verboom, ${ }^{\dagger}$ Sybolt Harkema, ${ }^{j}$ Walter Vogt, ${ }^{\ddagger}$ Volker Böhmer, ${ }^{*}$, and David N. Reinhoudt*,

Laboratories of Organic Chemistry and Chemical Physics, University of Twente, P.O. Box 217, 7500 AE Enschede, The Netherlands, and Institute of Organic Chemistry, Johannes Gutenberg University, D-6500 Mainz, West Germany

\section{Received March 1, 1990}

Calix [4]arenes ${ }^{1}$ are building blocks constructed from phenols and formaldehyde like cyclodextrins are built from glucose units. An important method to discriminate between the sugar units of cyclodextrins is to use capping reagents of different size. ${ }^{2}$ Depending on the shape of the bridge, selective A,C or A,D capping can be accomplished. In calixarene chemistry only a limited number of bridged calix[4]arenes are known. Two examples exist of calix[4] arenes with a bridge at the upper rim. ${ }^{3,4}$ At the lower rim $p$-tert-butylcalix[4]arene has been bridged with a poly (oxyethylene) chain (calix crowns), ${ }^{5,6}$ with a terphenyl unit (calix spherands), ${ }^{6}$ and with a ferrocene unit. ${ }^{7}$

Our objective was to cap p-tert-butylcalix[4]arene (1) at the lower rim with bridges of different shape and rigidity to be able to discriminate between the different phenolic hydroxyl groups and to fix the calix[4]arene in a rigid cone conformation. Such a discrimination is a prerequisite for the potential use of calix[4]arenes as building blocks for larger synthetic (receptor) systems.

\section{Results and Discussion}

CPK models suggested that benzophenone-3,3'-disulfonyl dichloride (2a), which is used in cyclodextrin chemistry for selective A,C capping, should also be a suitable bridging reagent for calix[4]arenes. Indeed, we found that slow addition of a solution of $2 \mathrm{a}$ in THF to a solution of the dipotassium salt of $p$-tert-butylcalix[4]arene

\footnotetext{
${ }^{\dagger}$ Laboratory of Organic Chemistry, University of Twente.

\$ Johannes Gutenberg University.

Laboratory of Chemical Physics, University of Twente.
}

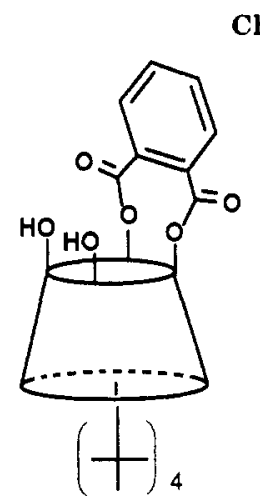

$3 f$
Chart I



5
(1) in THF resulted in the formation of the desired intrabridged compound $3 \mathrm{a}$ in $28 \%$ isolated yield (Scheme I). However, in addition to $20 \%$ of starting material, a second product was isolated in $9 \%$ yield, which was identified as the doubly interbridged bis(calix [4]arene) $\mathbf{4 a}$ by positive ion $\mathrm{FAB}$ mass spectrometry, consisting of two calix [4] arene units connected by two benzophenone-3,3'disulfonyl bridges. The ${ }^{1} \mathrm{H}$ NMR spectra of both compounds are very similar, showing two singlets for the tert-butyl groups, an $\mathrm{AB}$ system for the methylene bridge protons, and two singlets for the aromatic protons of the calix [4]arene, which was typical for a diametrically disubstituted calix[4]arene in a rigid cone conformation.

In order to study the effect of the nature of the bridge on the formation of mono- and bis(calix[4]arenes) we used the two capping units $2 \mathrm{~b}$ and $2 \mathrm{c}$, which have a structure similar to the benzophenone-3,3'-disulfonyl dichloride bridge (2a). (For structures and yields see Table I.) With use of diphenyl sulfone 3,3'-disulfonyl dichloride (2b) as a capping reagent, the overall yield dropped but the relative amount of bis(calix[4]arene) $\mathbf{4 b}$ increased significantly. In the case of benzophenone-3,3'-dicarboxylic acid dichloride (2c) only the singly intrabridged calix[4]arene $3 \mathrm{c}$ was isolated. A rationalization of the above results may be given in terms of the shape of the bridging unit. Probably the ring-closure reaction in the case of capping reagent $2 b$ is less efficient due to a nonoptimal fit, and therefore relatively more bis(calix [4]arene) is formed.

The 3,3'-substituted biphenyls $2 \mathrm{~d}$ and $2 \mathrm{e}$ have a good fit, but they are more rigid than compounds $2 \mathbf{a}-2 \mathbf{c}$; therefore, only singly intrabridged calix [4]arenes $3 \mathrm{~d}$ and $3 e$ were isolated. In the case of $3,3^{\prime}$-bis(bromomethyl)biphenyl (2e) the reaction conditions were changed to $\mathrm{K}_{2} \mathrm{CO}_{3} / \mathrm{CH}_{3} \mathrm{CN}$ because with $\mathrm{KOtBu} / \mathrm{THF}$ no bridged products could be isolated.

(1) For a review see: Gutsche, C. D. Calixarenes; Stoddart, F. J., Ed.; Monographs in Supramolecular Chemistry; The Royal Society of Chemistry: Cambridge, 1989; Vol. 1.

(2) Tabushi, I.; Shimokawa, K.; Fujita, K. Tetrahedron Lett. 1977, 1527. Tabushi, I.; Kuroda, Y.; Yokota, K.; Chi Yuan, L. J. Am. Chem. Soc. 1981, 103, 711. Tabushi, I.; Chi Yuan, L.; Shimokawa, K.; Yokota, K.; Mizutani, T.; Kuroda, Y. Tetrahedron Lett. 1981, 22, 2273. Tabushi, I.; Nabeshima, T.; Kitaguchi, H.; Yamamura, K. J. Am. Chem. Soc. 1982, 104, 2017. Tabushi, I.; Yamamura, K.; Nabeshima, T. J. Am. Chem. Soc. 1984, 106, 5267. Tabushi, I.; Nabeshima, T.; Fujita, K.; Matsunaga, A.; Imoto, T. J. Org. Chem. 1985, 50, 2638

(3) Goldmann, H.; Vogt, W.; Paulus, E.; Böhmer, V. J. Am. Chem. Soc. $1988,110,6811$.

(4) To be published.

(5) Alfieri, G.; Dradi, E.; Pochini, A.; Ungaro, R.; Andreetti, G. D. J. Chem. Soc., Chem. Commun. 1983, 1075.

(6) Dijkstra, P. J.; Brunink, J. A. J.; Bugge, K.-E.; Reinhoudt, D. N.; Harkema, S.; Ungaro, R.; Ugozzoli, F.; Ghidini, E. J. Am. Chem. Soc. $1989,111,7567$.

(7) Beer, P. D.; Keefe, A. D. J. Inclusion Phenom. 1987, 5, 499. 
Scheme I

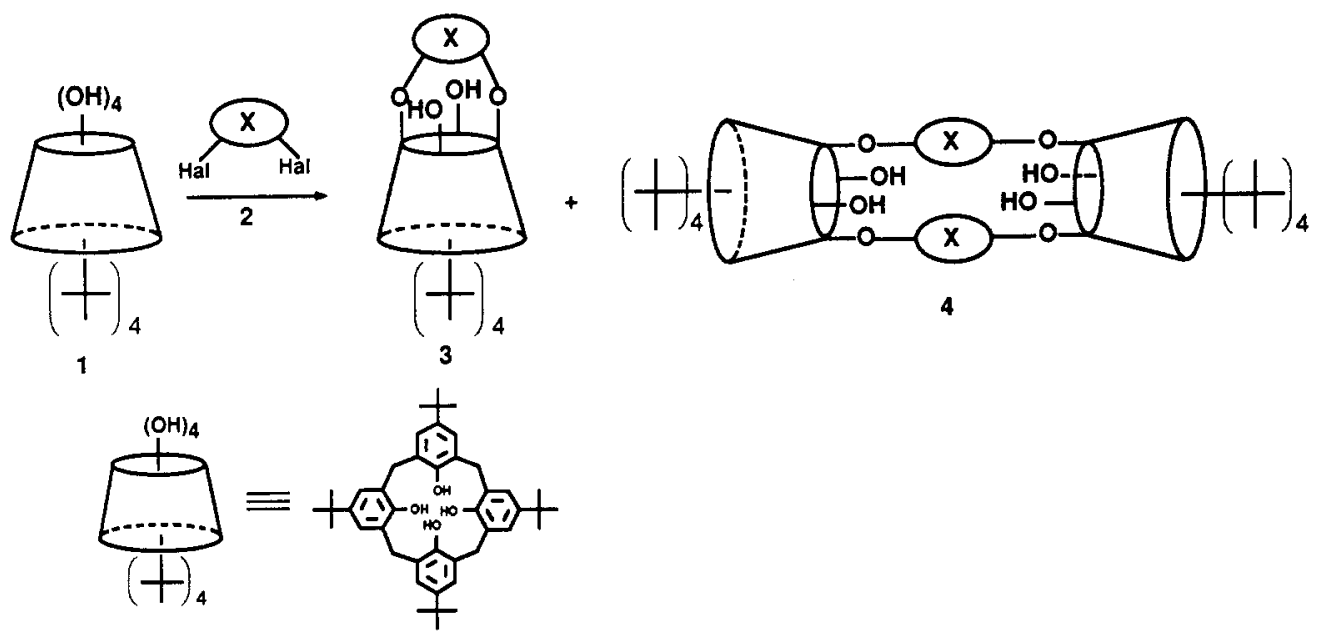

Table I. Reaction Conditions and Yields (\%) of the Reaction of 1 with $2 a-g$

\begin{tabular}{|c|c|c|c|c|c|c|}
\hline & $\begin{array}{l}\text { bridging } \\
\text { reagent } 2\end{array}$ & method & $\begin{array}{c}\text { addn } \\
\text { time, } \mathrm{h}\end{array}$ & 3 & 4 & recovered 1 \\
\hline $\mathbf{a}$ & & $\mathrm{A}^{a}$ & 24 & 28 & 9 & 20 \\
\hline b & & $\mathrm{A}^{a}$ & 24 & 9 & 9 & 20 \\
\hline c & & $\mathrm{A}^{a}$ & 8 & 26 & 0 & 7 \\
\hline d & & $\mathrm{A}^{a}$ & 9 & 20 & 0 & 30 \\
\hline e & & $\mathrm{B}^{b}$ & 6 & 39 & 0 & 0 \\
\hline f & & $A^{b}$ & 24 & $30^{c}$ & 0 & 26 \\
\hline & & $\mathrm{C}^{b}$ & 24 & $27^{d}$ & 0 & 22 \\
\hline g & & $\mathrm{B}^{a}$ & 4 & 86 & 0 & 0 \\
\hline
\end{tabular}

a Room temperature. 'Reflux. 'Proximally intrabridged calix[4]arene. 'Yield of doubly intrabridged calix[4]arene 5: $18 \%$.

Reaction (KOtBu/THF) of 1 with $o$-phthaloyl dichloride (2f) gave a singly intrabridged calixarene $3 f$ as the only product in $30 \%$ yield, in which two adjacent phenol rings are connected (Chart I). In this case, the distance between the reactive centers is too short to form a diametrically intrabridged compound. The ${ }^{1} \mathrm{H}$ NMR spectrum of $3 \mathrm{f}$ shows two singlets for the tert-butyl groups and three $A B$ systems in a ratio of 1:1:2 for the methylene bridge protons. To the best of our knowledge, this is the first example of a proximally intrabridged calix [4]arene. ${ }^{8}$ When 1 was reacted with 2 equiv of $\mathbf{2 f}$, with $\mathrm{CsF}$ as a base in refluxing

(8) Very recently Pappalardo described the first example of a proximally disubstituted calix [4]arene: Bottino, F.; Giunta, L.; Pappalardo, S. J. Org. Chem. 1989, 54, 5407 . acetonitrile, the doubly intrabridged calix[4]arene 5 was isolated from the reaction mixture in $18 \%$ yield in addition to $27 \%$ of $3 f$ and $22 \%$ of recovered 1 . Compound 5 exists in a rigid cone conformation according to the two $\mathrm{AB}$ systems for the methylene bridge protons and the singlet for the tert-butyl groups in the ${ }^{1} \mathrm{H}$ NMR spectrum.

Finally, the very flexible and reactive sebacoyl chloride $(2 \mathrm{~g})$ afforded the singly intrabridged calix[4]arene $3 \mathrm{~g}$ in $86 \%$ yield. In this case the reaction can be compared with the selective diametrical dialkylation. ${ }^{9}$ The crystal structure of this compound could be solved (Figure 1).

(9) van Loon, J.-D.; Arduini, A.; Verboom, W.; Ungaro, R.; van Hummel, G. J.; Harkema, S.; Reinhoudt, D. N. Tetrahedron Lett. 1989, 30 , 2681 . 
Table II. Melting Points and Characteristic Spectral Data of Compounds 3a-g, 4a,b, and $5^{\circ}$

\begin{tabular}{|c|c|c|c|c|c|c|c|c|c|c|c|}
\hline \multirow[b]{2}{*}{ compd } & \multirow[b]{2}{*}{$\mathrm{mp},{ }^{\circ} \mathrm{C}$} & \multicolumn{5}{|c|}{${ }^{1} \mathrm{H} \mathrm{NMR}\left(\mathrm{CDCl}_{3}\right), \delta$} & \multicolumn{4}{|c|}{${ }^{13} \mathrm{C} \mathrm{NMR}\left(\mathrm{CDCl}_{3}\right), \delta$} & \multirow[b]{2}{*}{$\begin{array}{c}\text { FAB-MS } \\
m / e(\mathbf{M}+1)^{+}\end{array}$} \\
\hline & & $\operatorname{ArH}(\mathrm{s})$ & $\mathrm{OH}(\mathrm{s})$ & $\begin{array}{c}\mathrm{ArCH} \mathrm{CH}_{2} \mathrm{Ar} \\
(\mathrm{AB} \mathrm{q})\end{array}$ & $J, \mathbf{H z}$ & $t$-Bu (s) & $\mathrm{C}=\mathrm{O}(\mathrm{s})$ & $\mathrm{ArC}-\mathrm{H}(\mathrm{d})$ & $\begin{array}{c}\mathrm{ArCH} \mathrm{A}_{2} \mathrm{Ar} \\
(\mathrm{t})\end{array}$ & $t-\mathrm{Bu}(\mathrm{q})$ & \\
\hline $3 \mathbf{a}$ & $200-3$ & $\begin{array}{l}6.86 \\
7.09\end{array}$ & 4.75 & $\begin{array}{l}3.49 \\
4.18\end{array}$ & 14.1 & $\begin{array}{l}0.93 \\
1.25\end{array}$ & 193.6 & $\begin{array}{l}125.3 \\
126.7\end{array}$ & 33.3 & $\begin{array}{l}30.8 \\
31.6\end{array}$ & 955 \\
\hline $\mathbf{3 b}$ & $>300 \mathrm{dec}$ & $\begin{array}{l}6.86 \\
7.11\end{array}$ & 4.23 & $\begin{array}{l}3.51 \\
4.27\end{array}$ & 14.3 & $\begin{array}{l}0.93 \\
1.20\end{array}$ & & $\begin{array}{l}125.5 \\
126.7\end{array}$ & 33.3 & $\begin{array}{l}30.5 \\
30.8\end{array}$ & 991 \\
\hline $3 \mathbf{c}$ & $>300 \mathrm{dec}$ & $\begin{array}{l}6.95 \\
7.11\end{array}$ & 5.26 & $\begin{array}{l}3.53 \\
3.87\end{array}$ & 14.4 & $\begin{array}{l}1.04 \\
1.06\end{array}$ & $\begin{array}{l}191.7 \\
164.4^{i}\end{array}$ & $\begin{array}{l}125.3 \\
126.4\end{array}$ & 34.2 & $\begin{array}{l}31.0 \\
31.4\end{array}$ & 883 \\
\hline 3d & $>300 \mathrm{dec}$ & $\begin{array}{l}6.95 \\
7.01\end{array}$ & 5.32 & $\begin{array}{l}3.53 \\
3.92\end{array}$ & 14.4 & $\begin{array}{l}1.04 \\
1.08\end{array}$ & 163.8 & $\begin{array}{l}125.9 \\
126.3\end{array}$ & 33.8 & $\begin{array}{l}31.0 \\
31.4\end{array}$ & 855 \\
\hline $3 \mathbf{e}$ & $>250 \mathrm{dec}$ & $\begin{array}{l}6.89 \\
6.95\end{array}$ & 5.03 & $\begin{array}{l}3.28 \\
4.22\end{array}$ & 13.0 & $\begin{array}{l}0.98 \\
1.18\end{array}$ & & $\begin{array}{l}125.4 \\
125.5\end{array}$ & 31.7 & $\begin{array}{l}31.1 \\
31.7\end{array}$ & 827 \\
\hline $3 f$ & $285 \mathrm{dec}$ & $\begin{array}{l}6.93^{b}, 7.19^{c} \\
7.03,7.27\end{array}$ & $e$ & $\begin{array}{l}3.57, f 3.32,3.58^{g} \\
4.28,3.97,3.99\end{array}$ & 13.7 & $\begin{array}{l}1.18 \\
1.26\end{array}$ & 165.3 & $\begin{array}{l}125.5,126.7 \\
125.8,127.0\end{array}$ & $\begin{array}{l}32.7,35.5 \\
33.1\end{array}$ & $\begin{array}{l}31.3 \\
31.4\end{array}$ & 779 \\
\hline $3 g$ & $>300 \mathrm{dec}$ & $\begin{array}{l}6.81 \\
7.13\end{array}$ & 5.43 & $\begin{array}{l}3.40 \\
3.90\end{array}$ & 14.0 & $\begin{array}{l}0.93 \\
1.35\end{array}$ & 171.6 & $\begin{array}{l}125.4 \\
125.8\end{array}$ & 32.7 & $\begin{array}{l}30.9 \\
31.7\end{array}$ & 815 \\
\hline $4 \mathbf{a}$ & $>300$ & $\begin{array}{l}6.73 \\
7.07\end{array}$ & 4.57 & $\begin{array}{l}3.27 \\
4.04\end{array}$ & 14.2 & $\begin{array}{l}0.88 \\
1.28\end{array}$ & 191.8 & $\begin{array}{l}125.6 \\
126.4\end{array}$ & 32.4 & $\begin{array}{l}30.8 \\
31.6\end{array}$ & $1910(\mathrm{M}+2)^{+}$ \\
\hline $4 b$ & $>240 \mathrm{dec}$ & $\begin{array}{l}6.77 \\
7.11\end{array}$ & 4.78 & $\begin{array}{l}3.30 \\
4.09\end{array}$ & 14.2 & $\begin{array}{l}0.90 \\
1.32\end{array}$ & & $j$ & $j$ & $j$ & $1982(\mathrm{M}+2)^{+}$ \\
\hline $\mathbf{5}$ & $>300$ & $\begin{array}{l}7.08^{d} \\
7.35\end{array}$ & & $\begin{array}{l}3.39,3.65^{h} \\
3.63,4.20\end{array}$ & 13.9 & 1.26 & 167.3 & $\begin{array}{l}126.3 \\
126.4\end{array}$ & $\begin{array}{l}31.5 \\
35.9\end{array}$ & 31.3 & 909 \\
\hline
\end{tabular}

${ }^{a}$ All compounds gave satisfactory elemental analyses. ${ }^{b}$ Doublets, $J=2.4 \mathrm{~Hz}$. ${ }^{c}$ Doublets, $J=2.5 \mathrm{~Hz}$. ${ }^{d}$ Doublets, $J=2.2 \mathrm{~Hz}$. ${ }^{\circ} \mathrm{The}$ OH signal is located in a multiplet of the bridge at $\delta 7.8-7.75$. ${ }^{f}$ The ratio of the $\mathrm{AB}$ q systems from left to right is $2: 1: 1 .{ }^{g} \mathrm{~J}=14.0 \mathrm{~Hz} .{ }^{h} \mathrm{~J}=13.0$ Hz. 'Carbonyl of ester function. $j$ Not determined due to low solubility.

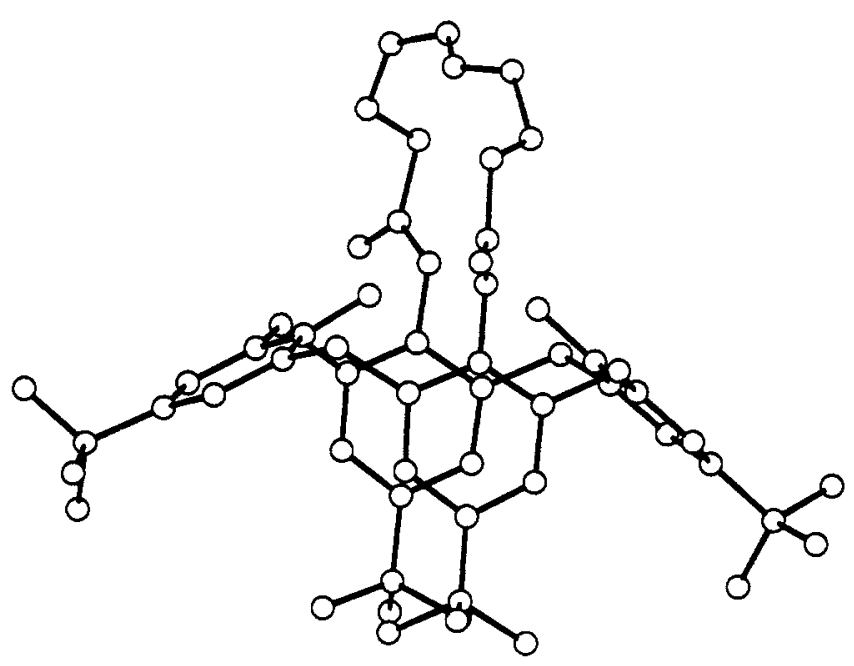

Figure 1. View of compound 3g.

The calix [4]arene has a distorted cone conformation. The phenol rings connected via the sebacoyl bridge are almost parallel with an angle of $2.1^{\circ}$. These rings are almost perpendicular to the mean plane through the connecting methylene groups (angles $96.1^{\circ}$ and $94.1^{\circ}$ ). The angle between the mean planes of the remaining two phenol groups is $111.8^{\circ}$. The angles of these planes with the mean "methylene plane" are $147.4^{\circ}$ and $144.4^{\circ}$.

We can conclude that diametrical and proximal capping of calix [4]arene 1 is possible, giving products in a rigid cone conformation. Depending on the structure of the difunctional reagent, bis(calix [4] arenes) can be synthesized also. ${ }^{10}$ Further reactions of calix[4]arenes 3 via the two remaining hydroxyl groups are under investigation.

\section{Experimental Section}

Melting points are uncorrected. ${ }^{1} \mathrm{H}$ NMR and ${ }^{12} \mathrm{C}$ NMR spectra were recorded in $\mathrm{CDCl}_{3}$ with $\mathrm{Me}_{4} \mathrm{Si}$ as internal standard. Positive

(10) For a rational design of bis(calix[4]arenes) see: Kraft, D.; van Loon, J.-D.; Owens, M.; Verboom, W.; Vogt, W.; McKervey, M. A.; Böhmer, V.; Reinhoudt, D. N. Submitted for publication. ion FAB mass spectra were recorded with use of $m$-nitrobenzyl alcohol as matrix.

All chemicals were reagent grade and were used without further purification. The difunctional reagents $2 \mathrm{f}$ and $2 \mathrm{~g}$ were obtained from Aldrich. Benzophenone-3,3'-disulfonyl dichloride ${ }^{11}$ (2a), diphenyl sulfone $3,3^{\prime}$-disulfonyl dichloride ${ }^{12}(2 \mathbf{b})$, benzophenone-3,3'-dicarboxylic acid dichloride ${ }^{13}(2 \mathrm{c})$, and $3,3^{\prime}$-bis(bromomethyl)biphenyl ${ }^{14}(2 e)$ were prepared according to literature procedures. Biphenyl-3,3'-dicarboxylic acid dichloride (2d) was prepared from its dimethyl ester ${ }^{15}$ by standard procedures. Tetrahydrofuran (THF) was freshly distilled over sodium/ benzophenone ketyl. Petroleum ether refers to the fraction boiling at $40-60^{\circ} \mathrm{C}$. Dropwise addition over a period of several hours was always carried out with a perfusor. All reactions were carried out under a nitrogen atmosphere. Solutions were dried over $\mathrm{MgSO}_{4}$.

General Procedures for the Reaction of Calix[4]arene 1 with Compounds 2a-2g. Method A. To a suspension of $p$. tert-butylcalix [4] arene (1) $(0.65 \mathrm{~g}, 1.0 \mathrm{mmol})$ in THF (125 mL; $200 \mathrm{~mL}$ in the case of $2 \mathrm{f})$ was added KOtBu $(0.23 \mathrm{~g}, 2.0 \mathrm{mmol})$. After being stirred for $30 \mathrm{~min}$ at room temperature, a solution of compounds $2 \mathrm{a}-\mathrm{d}, \mathrm{f}(1.08 \mathrm{mmol})$ in THF $(50 \mathrm{~mL} ; 70 \mathrm{~mL}$ in the case of $2 \mathrm{~d}$ due to the low solubility) was added dropwise to the reaction mixture. The addition times and reaction temperatures are given in Table I. After addition of a concentrated $\mathrm{NH}_{4} \mathrm{Cl}$ solution ( $15 \mathrm{~mL}$, not in the case of $2 \mathrm{f})$, most of the THF was removed under reduced pressure. $\mathrm{CH}_{2} \mathrm{Cl}_{2}(150 \mathrm{~mL})$ was added to the residue whereupon the organic layer was washed with brine $(2 \times 75 \mathrm{~mL})$. After removal of the solvent under reduced pressure, the residue was separated by flash chromatography ${ }^{16}$ [silica gel, $\mathrm{CH}_{2} \mathrm{Cl}_{2}$;petroleum ether $=4: 1(3 \mathrm{a}, \mathbf{b}, 4 \mathrm{a}, \mathbf{b}), \mathrm{CH}_{2} \mathrm{Cl}_{2}$;petroleum ether $=2: 1(3 \mathrm{c}), \mathrm{CH}_{2} \mathrm{Cl}_{2}$ :petroleum ether $=1: 2(3 \mathrm{~d}), \mathrm{CHCl}_{3}: \mathrm{Et}_{2} \mathrm{O}=99: 1$ (3f)] to afford pure compounds that could not be recrystallized

(11) Work, J. L.; Herweh, J. E. J. Polym. Sci. A 1968, 6, 2022

(12) Tyuleneva, I. M.; Moskvichev, Y. A.; Mironov, G. S.; Farberov, M. I.; Kryukova, G. G.; Titova, T. S.; Chernova, I. K.; Mandrosova, F. M Osnoun. Org. Sint. Neftekhim. 1975, 2, 93; Chem. Abstr. 1975, 83, $192731 x$.

(13) Ito, Y.; Kawatsuki, N.; Giri, B. P.; Yoshida, M.; Matsuura, T. J. Org. Chem. 1985, 50, 2893.

(14) Thulin, B.; Wennerström, O. Acta Chim. Scand. B 1983, 37, 297.

(15) Takagi, K.; Hayama, N.; Inokawa, S. Bull. Chem. Soc. Jpn. 1980, 53,3691 .

(16) The eluents were chosen so that the intrabridged compounds had an $R_{f}$ value of $0.3-0.5$. In cases in which doubly interbridged bis(calix[4]arenes) were formed, $R_{f}$ values of $0.1-0.2$ were observed for these compounds. 
from the usual organic solvents. In the cases of the compounds $3 c$ and $3 d$ an additional purification was performed by fractional precipitation from $\mathrm{CH}_{2} \mathrm{Cl}_{2} / \mathrm{Et}_{2} \mathrm{O}$ and $\mathrm{CH}_{2} \mathrm{Cl}_{2} / \mathrm{MeOH}$, respectively. The yields, melting points, and spectral data are summarized in Tables I and II.

Method B. To a suspension of p-tert-butylcalix [4]arene toluene complex (1) $(1.0 \mathrm{~g}, 1.36 \mathrm{mmol})$ in $\mathrm{CH}_{3} \mathrm{CN}(300 \mathrm{~mL})$ was added $\mathrm{K}_{2} \mathrm{CO}_{3}(0.38 \mathrm{~g}, 2.74 \mathrm{mmol})$. In the case of $2 \mathrm{e}$, a small amount of $\mathrm{KI}$ was added also. After being stirred for $30 \mathrm{~min}$ at reflux temperature (2e) or at room temperature $(2 \mathrm{~g})$, a solution of the bridging reagent $2 \mathrm{e}, \mathrm{g}$ in $\mathrm{CH}_{3} \mathrm{CN}(100 \mathrm{~mL})$ was added dropwise to the reaction mixture. The addition times and reaction temperatures are given in Table $I$. In the case of $2 \mathrm{e}$ the reaction mixture was refluxed for additional $16 \mathrm{~h}$. After removal of the $\mathrm{CH}_{3} \mathrm{CN}$ under reduced pressure, $\mathrm{CH}_{2} \mathrm{Cl}_{2}(150 \mathrm{~mL})$ was added to the residue whereupon the organic layer was washed with brine $(2 \times 75 \mathrm{~mL})$. After removal of the solvent under reduced pressure, the residue was purified by flash chromatography ${ }^{16}$ [silica gel, $\mathrm{CH}_{2} \mathrm{Cl}_{2}$ (3e), $\mathrm{CHCl}_{3}$ :petroleum ether $\left.=3: 1(3 \mathrm{~g})\right]$ to give pure compounds, which in the case of $3 e$ could not be recrystallized from the usual organic solvents. The yields, melting points, and spectral data are summarized in Tables I and II.

Method C. To a suspension of p-tert-butylcalix [4]arene (1) $(0.65 \mathrm{~g}, 1.0 \mathrm{mmol})$ in $\mathrm{CH}_{3} \mathrm{CN}(250 \mathrm{~mL})$ was added $\mathrm{CsF}(0.61 \mathrm{~g}$, $4.0 \mathrm{mmol}$ ). After the mixture was stirred for $30 \mathrm{~min}$, a solution of compound $2 \mathrm{f}(1.08 \mathrm{mmol})$ in THF $(50 \mathrm{~mL})$ was added dropwise to the refluxing reaction mixture in $24 \mathrm{~h}$. After removal of the solvent under reduced pressure, $\mathrm{CH}_{2} \mathrm{Cl}_{2}(150 \mathrm{~mL})$ was added to the residue whereupon the organic layer was washed with brine $(2 \times 75 \mathrm{~mL})$. After removal of the solvent under reduced pressure, the residue was separated by flash chromatography ${ }^{16}$ [silica gel, $\left.\mathrm{CH}_{2} \mathrm{Cl}_{2}: \mathrm{Et}_{2} \mathrm{O}=50: 1\right]$. The yields, melting points, and spectral data are summarized in Tables I and II.

X-ray Crystallography of Compound 3g. The crystal structure of compound $3 \mathbf{g}$ was determined by $\mathrm{X}$-ray diffraction. Crystal data: $\mathrm{C}_{54} \mathrm{H}_{70} \mathrm{O}_{6}$, orthorhombic, space group $P 22_{1} 2_{1} 2_{1}$; $a=$ 10.026 (2) $\AA, b=18.350$ (3) $\AA, c=26.679$ (5) $\AA, V=4908$ (1) $\AA^{3}$, $Z=4, d_{\text {calc }}=1.103 \mathrm{~g} \mathrm{~cm}^{-3}, \mu=0.65 \mathrm{~cm}^{-1}$. Reflections were measured in the $\omega / 2 \theta$ scan mode, using graphite-monochromated Mo $\mathrm{K} \alpha$ radiation [scan width $(\omega) 1.00+0.34 \tan \theta$ ]. The structure was solved by direct methods and refined with full-matrix least-squares methods. A total of 2523 reflections with $F_{0}^{2}>$ $3 \sigma\left(F_{0}{ }^{2}\right)$ was used in the refinement. The number of parameters refined was 361 [scale factor, positional and thermal parameters]. The final $R$ factors were $R=8.0 \%$ and $R_{w}=9.1 \%$. All calculations were done with SDP.17

In the crystal structure some disorder was found in the aliphatic chain, as evidenced by the high values of the thermal parameters in this part of the molecule. In order to keep the number of parameters small, thermal parameters were refined isotropically for $\mathrm{C}$ and $\mathrm{O}$ atoms, with the exception of the $\mathrm{C}$ atoms of the aliphatic bridge and the terminal $\mathrm{C}$ atoms of the tert-butyl groups, which were refined anisotropically. $H$ atoms were added in their calculated positions and treated as riding atoms in the refinement. No hydrogens were added to the aliphatic chain carbon atoms, because of the disorder found. The phenolic $\mathrm{H}$ atoms could not be located from a difference Fourier synthesis and have not been included in the refinements.

Acknowledgment. This investigation was supported by The Netherlands Foundation for Chemical Research (SON) with financial aid from The Netherlands Organization for Scientific Research (NWO) and EEC Twinning Project No. ST2J-0215. We also acknowledge J. M. Visser and J. L. M. Vrielink for recording the NMR, T. W. Stevens for recording the mass spectra, A. M. MontanaroChristenhusz for performing the elemental analyses, and I. Jansen and W. T. Reinalda for their contributions.

Registry No. 1, 60705-62-6; 2a, 17619-15-7; 2b, 7357-41-7; 2c, 6472-69-1; 2d, 6423-26-3; 2e, 24656-53-9; 2f, 88-95-9; 2g, 111-19-3 3a, 128217-27-6; 3b, 128217-28-7; 3c, 128217-29-8; 3d, 128242-26-2;

(17) Structure Determination Package, B. A. Frenz and Associates Inc., College Station, TX, and Enraf-Nonius, Delft, The Netherlands, 1983 3e, 128217-30-1; 3f, 128217-31-2; 3g, 128217-32-3; 4a, 128217-33-4; 4b, 128217-34-5; 5, 128217-35-6.

Supplementary Material Available: Figure showing 3a with atom labels and tables of positional and thermal parameters, bond distances, and angles ( 9 pages). Ordering information is given on any current masthead page.

\section{C-Nitration of 2,6-Di- and 2,4,6-Tri-tert-butylpyridine with Nitronium Tetrafluoroborate ${ }^{1}$}

George A. Olah,* Khosrow Laali, Omar Farooq, and Judith A. Olah

Donald P. and Katherine B. Loker Hydrocarbon Research Institute and Department of Chemistry, University of Southern California, University Park, Los Angeles, California 90089-1661

\section{Received December 18, 1989}

Electrophilic substitution of pyridine occurs preferentially on the heteroatom ( $\mathrm{N}$-substitution). Nitration of pyridine with mixed nitric-sulfuric acid gives a low yield of the 3-nitro product, indicative that the nitration is that of the pyridinium ion formed by protonation in the acid medium. ${ }^{2}$ The most convenient method of preparing 4-nitropyridine is that through nitration of pyridine $N$. oxide, followed by deoxygenation (for example with phosphorous trichloride). ${ }^{3}$ Nitronium salts when reacted with pyridine gave $N$-nitropyridinium salts ( $\mathrm{N}$-nitration). ${ }^{4}$ Nitration of 2,6-dimethylpyridine and 2,4,6-trimethylpyridine also occurred on nitrogen. The resulting pyridinium salts are effective transfer nitration reagents. ${ }^{5,6}$ Whereas 2,6-di-tert-butylpyridine ${ }^{7}$ has found extensive use as proton trap in synthetic chemistry, ${ }^{8}$ electrophilic chemistry of hindered pyridines has not been explored.

We have now found that when reacting sterically crowded 2,6-di- and 2,4,6-tri-tert-butylpyridine with nitronium tetrafluoroborate nitration occurred exclusively in the ring. Thus, when 2,6-di-tert-butylpyridine was reacted with $\mathrm{NO}_{2}{ }^{+} \mathrm{BF}_{4}^{-}$in dry $\mathrm{CH}_{2} \mathrm{Cl}_{2}$ or $\mathrm{CH}_{2} \mathrm{Cl}_{2}$ /sulfolane, apart from unreacted starting material, $28 \% 2,6$-di-tertbutyl-4-nitropyridine and 6\% 2,6-di-tert-butyl-3,4-dinitropyridine were formed.

Similarly, 2,4,6-tri-tert-butylpyridine when reacted with $\mathrm{NO}_{2}{ }^{+} \mathrm{BF}_{4}^{-}$in $\mathrm{CH}_{2} \mathrm{Cl}_{2}$ gave $36 \%$ 2,4,6-tri-tert-butyl-3nitropyridine as the only product after workup.

Removal of the tert-butyl groups by acid-catalyzed transalkylation was also attempted in an attempt to obtain nitropyridines. tert-Butylnitropyridines were refluxed over superacidic Nafion-H or with $\mathrm{CF}_{3} \mathrm{SO}_{3} \mathrm{H}$ in excess benzene.

(1) Aromatic Substitution. 59. For part 58, see: Olah, G. A.; Faroog, O.; F. Farnia, S. M.; Wu, A. J. Org. Chem. 1990, 55, 1516 .

(2) Olah, G. A.; Malhotra, R.; Narang, S. C.; Nitration: Methods and Mechanisms; VCH Publishers: New York, 1989.

(3) Norman, R. O. C. In Principles of Organic Synthesis; Chapman and Hall: London, 1978; $p 404$.

(4) Olah, G. A.; Olah, J. A.; Overchuk, N. A. J. Org. Chem. 1965, 30, 3373.

(5) Cupas, C. A.; Pearson, R. L. J. Am. Chem. Soc. 1968, 90, 4742

(6) Olah, G. A.; Narang, S. C.; Olah, J. A.; Pearson, R. L.; Cupas, C. A. J. Am. Chem. Soc. 1980, 102, 3507.

(7) Scalzi, F. V.; Golob, N. F. J. Org. Chem. 1971, 36, 2541. 2,6-Ditert-butyl-and 2,4,6-Tri-tert-butylpyridine are also commercially available (Aldrich).

(8) Stang, P. J.; Fisk, T. E. Synthesis 1979, 438. Stang, P. J.; Treptow, W. Ibid. 1980, 283. 